\title{
Genetic recombination after cell fusion of protoplasts from the facultative alkaliphile Bacillus sp. C-125
}

\author{
Rikizo Aono, Masahiro Ito, Keith Joblin† and Koki Horikoshi
}

Author for correspondence: Rikizo Aono. Fax: +81459245819.

Department of

Bioengineering, Faculty of

Bioscience and

Biotechnology, Tokyo

Institute of Technology,

Nagatsuta 4259, Yokohama

227, Japan

\begin{abstract}
Protoplasts were prepared from two auxotrophic and antibiotic-resistant strains (Met ${ }^{-} \mathrm{Nal}^{\prime}$ and $\mathrm{Thr}^{-}$Str', respectively) of the facultative alkaliphile Bacillus sp. C-125 by treatment with lysozyme. The protoplasts fused effectively in the presence of polyethylene glycol. Fusants obtained between two parental protoplasts were regenerated on solid medium containing the two antibiotics, nalidixic acid (Nal) and streptomycin (Str). Parental protoplasts were regenerated at high frequency (43-97\%) on non-selective medium but not on selective medium. The Nalr Str' fusants had the form of bacilli. Met and Thr markers segregated among the fusants with a predominantly $\mathrm{Met}^{+} \mathrm{Thr}^{+}$ phenotype. The exfusants seemed to restore the parental ploidy.
\end{abstract}

Keywords: Bacillus sp. C-125, alkaliphile, alkaliphilic Bacillus, protoplast fusion, cell fusion

\section{INTRODUCTION}

Most of the alkaliphilic microbes that have been isolated from various soils belong to the genus Bacillus (Horikoshi, 1991). These bacteria produce extracellular enzymes with $\mathrm{pH}$ optima in the alkaline region. Although cell fusion and transformation systems using protoplasts have been developed for genetically manipulated strains of Bacillus spp. (Schaeffer et al., 1976; Chang \& Cohen, 1979), little is known about the potential of these systems for modifying alkaliphilic bacteria. It is therefore interesting to establish techniques of genetic engineering for alkaliphilic strains of Bacillus spp. from the point of view of basic as well as applied microbiology. Recently, we described methods for converting some alkaliphilic bacteria into protoplasts and regenerating viable cells from the protoplasts (Aono et al., 1992, 1993).

We have now developed conditions for fusing protoplasts from the facultative alkaliphilic Bacillus sp. C-125 and report here the first successful use of cell fusion to produce genetically modified alkaliphilic bacteria.

\section{METHODS}

Bacterial strains. The facultative alkaliphile Bacillus sp. C-125 (deposited as FERM 7344 at The Fermentation Research Institute, Agency of Industrial Science and Technology, Min-

\footnotetext{
†Present address: Grasslands Research Centre, AgResearch Private Bag
} 11008, Palmerston North, New Zealand. istry of International Trade and Industry, Tsukuba, Japan; Aono \& Horikoshi, 1983) and two of its derivatives were used in this study. One strain, C-125-90, is resistant to streptomycin (Str) and requires threonine for growth (Aono \& Ohtani, 1990). The other strain, C-125-073, is nalidixic acid (Nal)-resistant and methionine-dependent. The latter strain is a spontaneous $\mathrm{Nal}^{\mathrm{r}}$ mutant of a $\mathrm{Met}^{-}$derivative obtained from the wild-type strain during this study.

Media and culture conditions. The bacteria were aerobically grown in a complex alkaline medium at $37^{\circ} \mathrm{C}$. This hypotonic medium ( $\mathrm{pH} 10)$ contained, per litre of deionized water: $\mathrm{K}_{2} \mathrm{HPO}_{4}, 13.7 \mathrm{~g} ; \mathrm{KH}_{2} \mathrm{PO}_{4}, 5.9 \mathrm{~g}$; citric acid, $0.34 \mathrm{~g}$; $\mathrm{MgSO}_{4} .7 \mathrm{H}_{2} \mathrm{O}, 0.05 \mathrm{~g}$; glucose, $5 \mathrm{~g}$; peptone, $5 \mathrm{~g}$; yeast extract, $1 \mathrm{~g}$; and $\mathrm{Na}_{2} \mathrm{CO}_{3}, 10.6 \mathrm{~g}$ (Aono, 1985). Two similar hypotonic media were prepared by adding $11.7 \mathrm{~g}$ of $\mathrm{NaCl}$ instead of $\mathrm{Na}_{2} \mathrm{CO}_{3}$ and adjusting to $\mathrm{pH} 7$ or 8.5 with $\mathrm{NaOH}$. When necessary, these media were solidified with $1.5 \%(\mathrm{w} / \mathrm{v})$ agar. The hypertonic medium for regeneration of protoplasts was modified from the DM-3 medium of Chang \& Cohen (1979). It consisted of yeast extract, $5 \mathrm{~g}$; casamino acids, $5 \mathrm{~g}$; glucose, $20 \mathrm{~g}$; agar, $10 \mathrm{~g}$; bovine serum albumin, $0.4 \mathrm{~g}$; in 1 litre of deionized water containing $30 \mathrm{mM} \mathrm{MgCl}, 1.25 \mathrm{mM} \mathrm{CaCl}$, $0.5 \mathrm{M}$ monosodium succinate and $30 \mathrm{mM}$ Tris/ $\mathrm{HCl}(\mathrm{pH} 6.8)$.

The auxotrophy of the bacterial strains was examined on the alkaline synthetic medium ( $\mathrm{pH} 10 \cdot 3)$ described by Aono \& Ohtani (1990). This medium contained, per litre of deionized water: $\mathrm{K}_{2} \mathrm{HPO}_{4}, 13.7 \mathrm{~g} ; \mathrm{KH}_{2} \mathrm{PO}_{4}, 5.9 \mathrm{~g}$; citric acid, $0.34 \mathrm{~g}$; $\mathrm{MgSO}_{4} .7 \mathrm{H}_{2} \mathrm{O}, 0.05 \mathrm{~g} ; \mathrm{Na}_{2} \mathrm{CO}_{3}, 10.6 \mathrm{~g} ;\left(\mathrm{NH}_{4}\right)_{2} \mathrm{SO}_{4}, 1 \mathrm{~g}$; $\mathrm{KNO}_{3}, 1 \mathrm{~g}$; glucose, $5 \mathrm{~g}$; agar, $15 \mathrm{~g}$.

Preparation of protoplasts. Each strain was grown in the complex alkaline medium. Cells in exponential phase were harvested by centrifugation $\left(3000 \mathrm{~g}, 10 \mathrm{~min}, 4^{\circ} \mathrm{C}\right)$ and washed 
once with the SMMD medium of Wyrick \& Rogers (1973). The neutral SMMD medium contained $0.5 \mathrm{M}$ sucrose, $20 \mathrm{mM}$ $\mathrm{MgCl}_{2}, 20 \mathrm{mM}$ maleic acid and $0.05 \% \mathrm{DNase}$ I. This medium was adjusted to $\mathrm{pH} 7 \cdot 0$ with $\mathrm{NaOH}$. The cells were resuspended in SMMD to an $\mathrm{OD}_{660}$ of 15-20. Then 0.01 vols $1 \%(\mathrm{w} / \mathrm{v})$ lysozyme solution was added to the suspension. This mixture was spread thinly in a vessel to allow a good supply of air for the organism, and allowed to stand at $37^{\circ} \mathrm{C}$ to permit digestion of the peptidoglycan layers. Protoplast formation was monitored by microscopic observation. Protoplasts were recovered by centrifugation $\left(1000 \mathrm{~g}, 30 \mathrm{~min}, 10^{\circ} \mathrm{C}\right)$ and washed twice with SMMD medium. The protoplasts were counted with a Thoma's haematocytometer. The number of cells with intact cell walls was determined by counting colonies formed on the hypotonic alkaline medium.

Fusion of the protoplasts and selection of fusants. Fusion of protoplasts prepared from cells in exponential phase $\left(\mathrm{OD}_{660} 0.5\right)$ was attempted using four slightly modified methods described below.

(i) Method 1. Protoplasts prepared from C-125-073 and C-12590 were separately resuspended in SMMD medium at a concentration of $2 \times 10^{9}-4 \times 10^{9}$ cells $\mathrm{ml}^{-1}$. These suspensions were used throughout in Methods $1-4$. Samples $(0.5 \mathrm{ml})$ of the suspensions were mixed and centrifuged $\left(1000 \mathrm{~g}, 10 \mathrm{~min}, 4{ }^{\circ} \mathrm{C}\right)$ and the pellet was resuspended in $0.1 \mathrm{ml}$ SMMD medium. SMMD $(0.9 \mathrm{ml})$ containing $40 \%(\mathrm{w} / \mathrm{v})$ polyethylene glycol 4000 was added to this suspension. The mixture was incubated in an ice-water bath for $1 \mathrm{~min}$ and plated on hypertonic regeneration medium containing nalidixic acid $\left(0.03 \mathrm{mg} \mathrm{ml}^{-1}\right)$ and streptomycin $\left(3 \mathrm{mg} \mathrm{ml}^{-1}\right)$. Cells resistant to both nalidixic acid and streptomycin were grown at $37^{\circ} \mathrm{C}$. This method was used as a standard method in this study.

(ii) Method 2. The protoplast suspensions $(0.5 \mathrm{ml})$ were separately centrifuged as described above. Each pellet was resuspended in $0.05 \mathrm{ml} \mathrm{SMMD} \mathrm{medium} \mathrm{and} \mathrm{the} \mathrm{suspensions} \mathrm{were}$ mixed. After addition of SMMD-polyethylene glycol $(0.9 \mathrm{ml})$, the mixture was incubated in an ice-water bath for $1 \mathrm{~min}$, and plated on regeneration medium. This method does not comprise co-centrifugation of the two parental protoplasts.

(iii) Method 3. The protoplast suspensions $(0.5 \mathrm{ml})$ were mixed and the mixture was centrifuged as described above. The pellet was resuspended in $1 \mathrm{ml}$ SMMD without polyethylene glycol. The suspension was incubated in an ice-water bath for 1 min and plated on the regeneration medium. In this method, the protoplasts were not treated with polyethylene glycol.

(iv) Method 4. The mixture described in Method 3 was incubated in an ice-water bath without centrifugation, and plated on the regeneration medium. In this method, the two parental protoplasts were simply mixed.

Electron microscopy. Whole cells growing in the culture were fixed with glutaraldehyde by mixing with equal volumes of $8 \%$ $(\mathrm{v} / \mathrm{v})$ glutaraldehyde. Protoplasts suspended in SMMD were fixed by mixing the suspension with $8 \%$ glutaraldehyde in SMMD. Mixtures were incubated at room temperature for $1-2 \mathrm{~h}$ and then at $4{ }^{\circ} \mathrm{C}$ overnight. Samples were sedimented by centrifugation $\left(1000 \mathrm{~g}, 15 \mathrm{~min}, 20^{\circ} \mathrm{C}\right)$, and resuspended in either $0.1 \mathrm{M}$ sodium cacodylate buffer $(\mathrm{pH} 7 \cdot 2)$ containing $4 \%$ $(\mathrm{v} / \mathrm{v})$ glutaraldehyde (whole cells) or in the same buffer containing, glutaraldehyde and $0.5 \mathrm{M}$ sucrose (protoplasts) for several days. The fixed samples were washed with $0 \cdot 1 \mathrm{M}$ potassium phosphate buffer ( $\mathrm{pH} 7 \cdot 2$ ), post-fixed with $\mathrm{OsO}_{4}$ at $4{ }^{\circ} \mathrm{C}$, dehydrated and embedded in epoxy resin. Sections stained with uranyl acetate and costained with lead citrate were observed in a Philips $201 \mathrm{C}$ T electron microscope.
DNA determination. The bacterial cells were harvested by centrifugation $\left(8000 \mathrm{~g}, 10 \mathrm{~min}, 4{ }^{\circ} \mathrm{C}\right)$, washed twice with $0.1 \mathrm{M}$ potassium phosphate buffer $(\mathrm{pH} 7 \cdot 0)$ and broken by sonication. DNA was determined by the indole- $\mathrm{HCl}$ method (Ceriotti, 1955) with dAMP as the standard.

Protein determination. The concentration of proteins in the sonicated lysates described above was determined by the Lowry method, with BSA as a reference standard.

Materials. Polyethylene glycol 4000 was from Nakarai Tesque. Hen egg white lysozyme and DNase I were from Sigma.

\section{RESULTS AND DISCUSSION}

\section{Fusion of protoplasts from the facultative alkaliphilic strain of Bacillus sp. C-125}

The A1, type of peptidoglycan in the cell walls of strain C125 is readily digested with hen egg white lysozyme to yield protoplasts that are stable at neutral but not at alkaline pH (Aono \& Horikoshi, 1983; Aono et al., 1984, $1992,1993)$. In this study, the process of cell wall digestion was monitored by electron microscopy. The rod-shaped cells of C-125 (Fig. 1a) have a defined nuclear area similar in appearance to that in Bacillus alcalopbilus (Krulwich, 1982). After $10 \mathrm{~min}$, cell walls were partially digested, but the cells retained their rod shape (Fig. 1b). After $50 \mathrm{~min}$, all cells were spherical, and had cytoplasmic membrane but no cell wall (Fig. 1c). These observations indicated that the rigid layer of the cell walls of the organism was lysozyme-sensitive peptidoglycan, as suggested by previous chemical analyses of cell walls (Aono \& Horikoshi, 1983; Aono et al., 1984). Fusion among these protoplasts was found at a low frequency (Fig. 1d). Although fused protoplasts were rarely found, this finding prompted a trial to establish a genetic recombination system for this organism through cell fusion.

The conditions for effective regeneration of protoplasts from strain C-125 have recently been established (Aono et al., 1993). The results of protoplast regeneration obtained during these studies are given in Table 1 . Colony counts indicated that a high proportion $(43-97 \%)$ of the protoplasts prepared from strain C-125-073 $\left(\mathrm{Nal}^{\mathrm{r}}\right), \mathrm{C}-125-$ $90\left(\mathrm{Str}^{\mathrm{r}}\right)$ and the fusion mixtures regenerated cell walls when grown on the neutral hypertonic medium. However, these protoplasts regenerated very poorly on the alkaline hypotonic medium on which intact cells of the strain grew well. The frequency of colonies formed on alkaline medium was less than $3 \times 10^{-9}$. These results indicated that the protoplast suspensions contained few intact cells.

Fusants resistant to both nalidixic acid and streptomycin were identified by growth on neutral hypertonic medium containing the two antibiotics. $\mathrm{Nal}^{\mathrm{r}} \mathrm{Str}^{\mathrm{r}}$ clones appeared with a frequency of about $2 \times 10^{-6}$ of the mixed protoplasts treated by Method 1 or 2, whereas protoplasts derived from either of the parent strains failed to regenerate on this medium. It is concluded that the resistant cells resulted from fusion of $\mathrm{Nal}^{\mathrm{r}}$ protoplasts with $\operatorname{Str}^{\mathrm{r}}$ ones rather than from spontaneous mutation of 

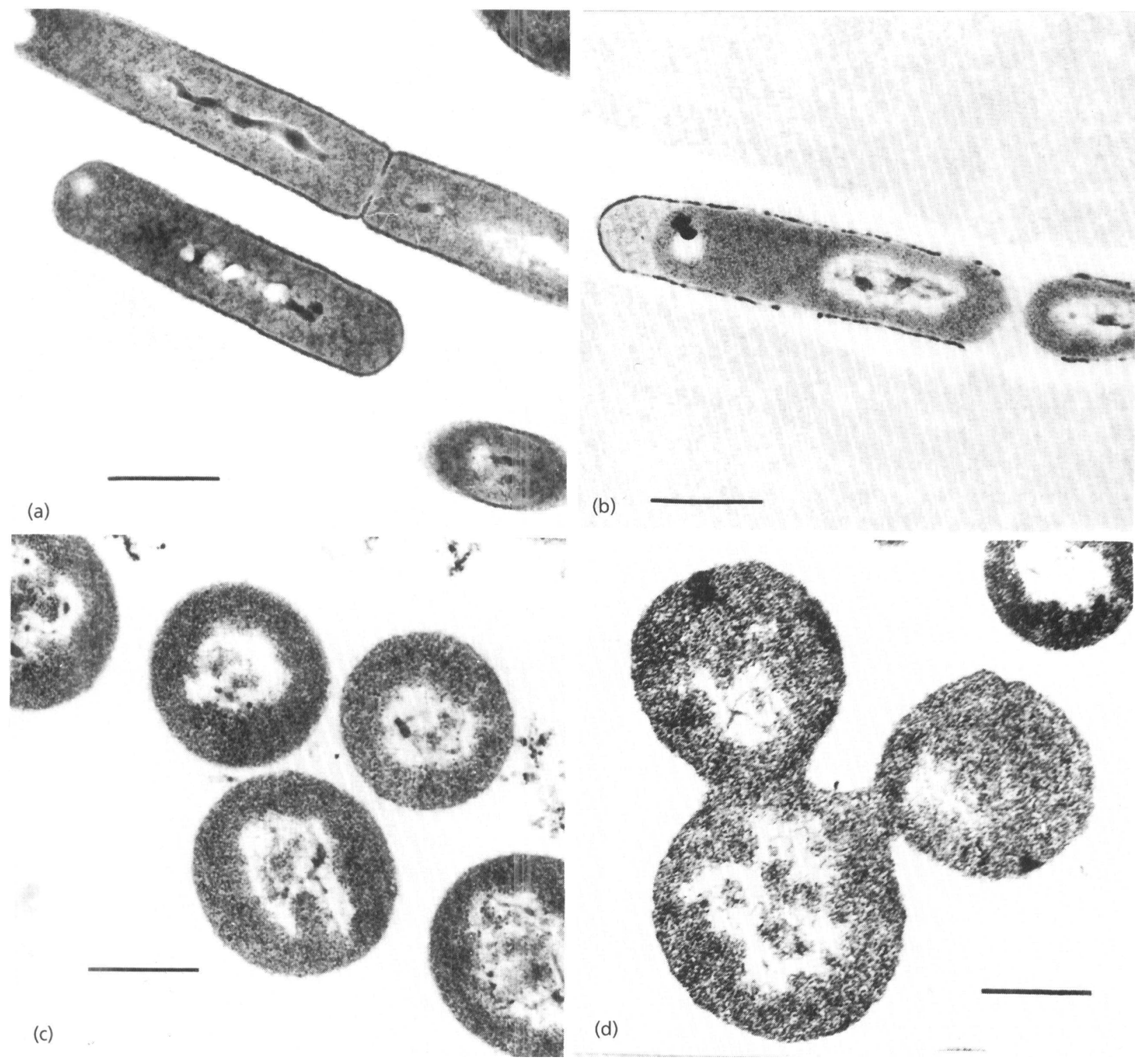

(b)

(d)

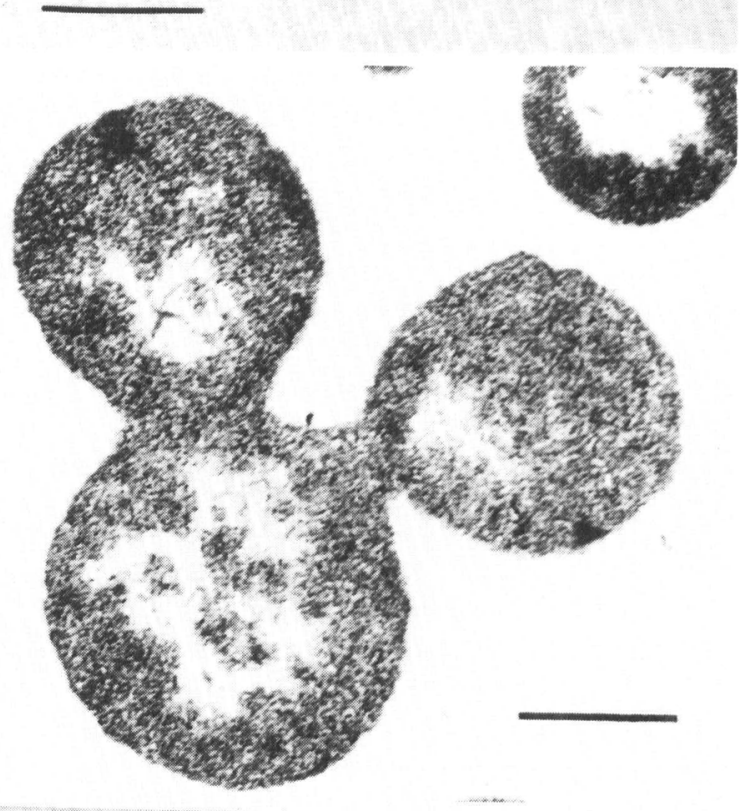

Fig. 1. Transmission electron micrographs of cells and protoplasts from Bacillus sp. C-125. Bacillus sp. C-125 was grown in complex medium ( $\mathrm{pH} \mathrm{8.5)}$ at $37^{\circ} \mathrm{C}$ for $5 \mathrm{~h}$. Cells were precipitated from the culture $\left(\mathrm{OD}_{660} 1.0\right)$ and treated with lysozyme $\left(0.1 \mathrm{mg} \mathrm{ml}{ }^{-1}\right)$ at $37^{\circ} \mathrm{C}$. (a) Intact cells growing in the culture; (b) cell treated with lysozyme for 10 min; (c) cells treated for $50 \mathrm{~min}$; (d) protoplasts fused in the absence of polyethylene glycol. All the photographs were taken at the same magnification. Bars, $0.5 \mu \mathrm{m}$.

C-125-073 to $\operatorname{Str}^{\mathrm{r}}$ or of $\mathrm{C}-125-90$ to $\mathrm{Nal}^{\mathrm{r}}$. Also, mixtures treated without the addition of polyethylene glycol yielded no $\mathrm{Nal}^{\mathrm{r}} \mathrm{Str}^{\mathrm{r}}$ clones. These results indicated that the addition of polyethylene glycol greatly enhanced the effective fusion of the protoplasts prepared from this organism.

\section{Genome ploidy of the Nal' Str' fusants}

Five Nal ${ }^{r}$ Str $^{r}$ fusants (C-125-F1 to -F5) were randomly selected from the experiment shown in Table 1. They were purified by two consecutive rounds of streaking for single colony selection carried out on neutral hypotonic agar containing streptomycin and nalidixic acid, because the drugs were unstable at alkaline $\mathrm{pH}$. These exfusants were grown in hypotonic broth $(\mathrm{pH} \mathrm{8.5)}$. Under these conditions, all strains grew as predominantly isolated cells with few short chains during the exponential phase. Doubling times measured by the increase in $\mathrm{OD}_{660}$ were about $70 \mathrm{~min}$, except for the parent strain, C-125-90, which had a doubling time of $100 \mathrm{~min}$. This strain grows slowly at $\mathrm{pH} 8.5$ compared with the other parent strain, C125-073, because it is an alkali-sensitive mutant (Aono \& Ohtani, 1990). 
Table 1. Colony formation from regenerated protoplasts of parental strains and after protoplast fusion

\begin{tabular}{|lcccc|}
\hline Strain & $\begin{array}{c}\text { Protoplasts* } \\
\left(\mathbf{m l}^{-1}\right)\end{array}$ & \multicolumn{3}{c|}{ Colonies $\left(\mathrm{ml}^{-1}\right) \dagger$} \\
\cline { 3 - 5 } & & $\begin{array}{c}\text { On neutral } \\
\text { hypertonic } \\
\text { medium }\end{array}$ & $\begin{array}{c}\text { On alkaline } \\
\text { hypotonic } \\
\text { medium }\end{array}$ & $\begin{array}{c}\text { On Nal, Str } \\
\text { hypertonic } \\
\text { medium } \ddagger\end{array}$ \\
\hline C-125-073 & $2 \cdot 9 \times 10^{9}$ & $2 \cdot 8 \times 10^{9}(0 \cdot 97)$ & $<10\left(<3 \times 10^{-9}\right)$ & $<10\left(<3 \times 10^{-9}\right)$ \\
C-125-90 & $3 \cdot 7 \times 10^{9}$ & $1.6 \times 10^{9}(0 \cdot 43)$ & $<10\left(<3 \times 10^{-9}\right)$ & $<10\left(<3 \times 10^{-9}\right)$ \\
Mixture 1S & ND & ND & ND & $6.8 \times 10^{3}\left(2 \cdot 1 \times 10^{-6}\right)$ \\
Mixture 2S & ND & ND & ND & $4.8 \times 10^{3}\left(1.5 \times 10^{-6}\right)$ \\
Mixture 3S & ND & ND & ND & $<10\left(<3 \times 10^{-9}\right)$ \\
Mixture 4S & $3.3 \times 10^{9}$ & $2 \cdot 4 \times 10^{9}(0 \cdot 73)$ & $<10\left(<3 \times 10^{-9}\right)$ & $<10\left(<3 \times 10^{-9}\right)$ \\
\hline
\end{tabular}

ND, Not determined.

* Counted by microscopy using a Thoma's haematocytometer.

† Colony numbers per $\mathrm{ml}$ of suspension spread on each plate. Colonies were counted every day for $5 \mathrm{~d}$ of incubation. Ratios of colonies to protoplasts incubated on the plates are given in parentheses. The ratios in mixtures have been calculated using the protoplast number measured in mixture 4.

$\ddagger$ Neutral regeneration medium contained nalidixic acid $\left(0.03 \mathrm{mg} \mathrm{ml}^{-1}\right)$ and streptomycin $\left(3 \mathrm{mg} \mathrm{ml}^{-1}\right)$.

$\$$ Mixtures $1-4$ are described in Methods.

\section{Table 2. Characteristics of Str ${ }^{r}$ and Nalr fusants}

Parental strains and five exfusants obtained from the experiments described in Table 1 were grown aerobically at $\mathrm{pH} 8.5$. The cells were harvested at late exponential phase and suspended in $0.1 \mathrm{M}$ potassium phosphate buffer $(\mathrm{pH} 7 \cdot 0)$. This suspension was divided into two parts and treated as described below.

\begin{tabular}{|c|c|c|c|c|c|c|c|}
\hline \multirow[t]{2}{*}{ Strain } & \multirow[t]{2}{*}{$O D_{660} *$} & \multirow[t]{2}{*}{$\begin{array}{c}10^{-9} \times \text { Cell } \\
\text { number } \\
\left(\mathrm{ml}^{-1}\right) \dagger\end{array}$} & \multicolumn{2}{|c|}{$\begin{array}{c}\text { Content } \\
{\left[\mu \mathrm{g}\left(\mathrm{OD}_{660} \text { unit }\right)^{-1}\right.} \\
\left.\mathrm{ml}^{-1}\right] \ddagger\end{array}$} & \multicolumn{2}{|c|}{$\begin{array}{c}10^{15} \times \text { Content } \\
(\mathrm{g} \text { per cell }) \subseteq\end{array}$} & \multirow[t]{2}{*}{$\begin{array}{l}\text { Ratio of } \\
\text { DNA to } \\
\text { protein }\end{array}$} \\
\hline & & & DNA & Protein & DNA & Protein & \\
\hline C-125-073 & $1 \cdot 41$ & $3 \cdot 34(100 \%)$ & $12 \cdot 1 \pm 0 \cdot 14$ & $238 \pm 6$ & $3 \cdot 62 \pm 0 \cdot 04$ & $71 \cdot 3 \pm 1 \cdot 7$ & 0.05 \\
\hline C-125-90 & $1 \cdot 56$ & $3.13(94 \%)$ & $11 \cdot 5 \pm 0 \cdot 18$ & $239 \pm 10$ & $3.67 \pm 0.06$ & $76 \cdot 4 \pm 3 \cdot 3$ & 0.05 \\
\hline C-125-F1 & $1 \cdot 36$ & $3.74(112 \%)$ & $13 \cdot 7 \pm 0 \cdot 50$ & $257 \pm 1$ & $3 \cdot 67 \pm 0 \cdot 13$ & $68 \cdot 6 \pm 0 \cdot 2$ & $0 \cdot 05$ \\
\hline $\mathrm{C}-125-\mathrm{F} 2$ & $1 \cdot 47$ & $3 \cdot 61(108 \%)$ & $11 \cdot 6 \pm 0 \cdot 67$ & $253 \pm 8$ & $3 \cdot 21 \pm 0 \cdot 23$ & $69 \cdot 9 \pm 2 \cdot 6$ & 0.05 \\
\hline C-125-F3 & $1 \cdot 52$ & $3.35(100 \%)$ & $13 \cdot 3 \pm 0 \cdot 32$ & $238 \pm 5$ & $3 \cdot 97 \pm 0 \cdot 10$ & $71 \cdot 0 \pm 1 \cdot 7$ & 0.06 \\
\hline C-125-F3 & $1 \cdot 46$ & $3.07(92 \%)$ & $11 \cdot 4 \pm 0 \cdot 41$ & $248 \pm 14$ & $3 \cdot 71 \pm 0 \cdot 13$ & $80 \cdot 7 \pm 4 \cdot 6$ & 0.05 \\
\hline $\mathrm{C}-125-\mathrm{F} 4$ & $1 \cdot 33$ & $3.49(104 \%)$ & $13 \cdot 8 \pm 0 \cdot 29$ & $248 \pm 8$ & $3 \cdot 96 \pm 0 \cdot 08$ & $71 \cdot 0 \pm 2 \cdot 4$ & 0.06 \\
\hline
\end{tabular}

* Measured at the time of harvest.

† To one of the cell suspensions, an equal volume of twofold strength neutral SMMD medium was added. Protoplasts were prepared and counted, as described in Methods. The protoplast number is presented as cell number per $\mathrm{OD}_{660}$ unit per $\mathrm{ml}$ of culture volume at the time of harvest. The ratio of cell number of each strain to that of C-125-073 is shown in parentheses.

$\ddagger$ The other cell suspension was sonicated. Mean values of DNA and protein content ( \pm SEM) were calculated from two determinations in the sonicated lysate.

$\S$ Values for DNA and protein content $(\ddagger)$ were divided by the cell number $(\dagger)$.

Cells in the late exponential phase $\left(\mathrm{OD}_{660} 1 \cdot 3-1 \cdot 6\right)$ were examined for cell size, and their DNA and protein content (Table 2). These cultures contained cells at different stages of growth and it was difficult to determine cell length accurately. In such a case, cell size might not be a good criterion for ploidy of the exfusants. Instead of cell 
dimensions, we compared optical density and cell number of the cultures. Cell numbers were determined microscopically after conversion of isolated cells or chains of cells into protoplasts (Fig. 1). The isolated protoplasts were easily counted with a haematocytometer. Counting the protoplasts was expected to give a more accurate number of total cells than counting the number of growing cells. The number of cells was $3.1-3.7 \times 10^{9}$ cells $\left(\mathrm{OD}_{660} \text { unit }\right)^{-1} \mathrm{ml}^{-1}$. These values were relatively constant between the parents and fusants. The values for the five fusants were between 92 and $112 \%$ of the parent strain, C$125-073$. These results suggested that cell volume was not so different between the strains.

The DNA and protein contents are shown in Table 2 as values standardized for OD or for single cells. The content and ratio of DNA to protein were similar in the parental strains. Therefore, these values could be considered as good criteria for ploidy. The contents per OD unit and the ratios found in the exfusants were not greatly different from those found in the parents. Comparison of these values and the cell number per OD unit gave amounts of DNA and protein per cell. In this case, also, the values were similar between the strains.

DNA determination was based on the cell deoxyribose content (Ceriotti, 1955). The results allowed us to calculate the amount of deoxyribose present in single cells. The DNA content per cell $\left(3.62-3.97 \times 10^{-15} \mathrm{~g}\right)$ corresponds to $1.15-1.26 \times 10^{-17} \mathrm{~mol}$ or $6.96-7.63 \times 10^{6}$ molecules of deoxyribose. If all of the sugar determined in this experiment is derived from a double strand of DNA, the size of this DNA would be 3.5-3.8 Mb. These values are similar to those of haploid chromosomes found in eubacteria.

These results suggest that the genome ploidy of the exfusants is identical to that of the parental strains, as previously shown for Bacillus subtilis exfusants which were haploid like their parents (Hauser \& Karamata, 1992).

\section{Genetic recombination during protoplast fusion}

In this study, each parental strain possessed antibiotic resistance and an auxotrophic marker. Only the antibiotic resistance markers were used for selection during growth on the regeneration medium. From the $\mathrm{Nal}^{\mathrm{r}}$ and $\mathrm{Str}^{\mathrm{r}}$ fusants, 62 strains were randomly selected and examined for methionine or threonine requirement by growth on alkaline synthetic medium (Table 3 ). All combinations of the auxotrophic markers were found in the fusants, with the $\mathrm{Met}^{-} \mathrm{Thr}^{-}$class being the least frequent. Of the recombinants, $71 \%$ were $\mathrm{Met}^{+}$and $81 \%$ were $\mathrm{Thr}^{+} . \mathrm{Nal}^{\mathrm{r}}$ $\mathrm{Str}^{\mathrm{r}} \mathrm{Met}^{+} \mathrm{Thr}^{-}$and $\mathrm{Nal}^{\mathrm{r}} \mathrm{Str}^{\mathrm{r}} \mathrm{Met}^{-} \mathrm{Thr}^{+}$clones appeared with much lower frequency than $\mathrm{Nal}^{\mathrm{r}} \mathrm{Str}^{\mathrm{r}} \mathrm{Met}^{+} \mathrm{Thr}^{+}$. However, the occurrence of these phenotypes indicates that recombination between the auxotrophic markers did take place in the fused protoplasts. We have no information on the physical distance between nal, str, met and $t b r$ genes on the chromosome of this organism. Therefore, further discussion about the recombination rates found in the exfusants would be without meaning.
Table 3. Genetic recombination between unselected markers among the Nal' Str' fusants

Unselected auxotrophic markers were examined among $62 \mathrm{Str}^{\mathrm{r}}$ $\mathrm{Nal}^{\mathrm{r}}$ exfusants obtained from the experiments described in Table 2.

\begin{tabular}{|lcc|}
\hline Phenotype & Number & $\begin{array}{c}\text { Frequency } \\
\text { (\%) }\end{array}$ \\
\hline Met $^{+} \mathrm{Thr}^{+}$ & 34 & 55 \\
Met $^{+} \mathrm{Thr}^{-}$ & 10 & 16 \\
Met $^{-} \mathrm{Thr}^{+}$ & 16 & 26 \\
Met $^{-} \mathrm{Thr}^{-}$ & 2 & 3 \\
\hline
\end{tabular}

However, it can be concluded that protoplast fusion led to pooling of the different parental chromosomes and allowed recombination in the alkaliphilic Bacillus sp. C125.

Cell fusion using protoplasts has been established in several species of Bacillus (Schaeffer et al., 1976; Chang \& Cohen, 1979; Bourne \& Dancer, 1986). The results described here show for the first time that protoplast fusion leads to recombinant alkaliphilic bacilli. It appears that cell fusion via protoplasts may provide a convenient method for genetic manipulation in alkaliphilic bacteria, which is essential for genetic studies and useful for industrial purposes.

\section{ACKNOWLEDGEMENTS}

This work was partially supported by a grant for 'Biodesign Research Program' from RIKEN to R. Aono. The authors thank D. H. Hopcroft and R. J. Bennett for technical assistance with electron microscopy.

\section{REFERENCES}

Aono, R. (1985). Isolation and partial characterization of structural components of the walls of alkalophilic Bacillus strain C-125.J Gen Microbiol 131, 105-111.

Aono, R. \& Horikoshi, K. (1983). Chemical composition of cell walls of alkalophilic strains of Bacillus. J Gen Microbiol 129, 1083-1087.

Aono, R. \& Ohtani, M. (1990). Loss of alkalophily in cell-wallcomponent-defective mutants derived from alkalophilic Bacillus C125. Biocbem J 266, 933-936.

Aono, R., Horikoshi, K. \& Goto, S. (1984). Composition of the peptidoglycan of alkalophilic Bacillus spp. J Bacteriol 157, 688-689.

Aono, R., Ito, M. \& Horikoshi, K. (1992). Instability of the protoplast membrane of facultative alkaliphilic Bacillus sp. C- 125 at alkaline $\mathrm{pH}$ values below the $\mathrm{pH}$ optimum for growth. Biochem $J$ 285, 99-103.

Aono, R., Ito, M. \& Horikoshi, K. (1993). Regeneration of protoplasts prepared from alkaliphilic strains of Bacillus spp. Biosci Biotechnol Biochem 57, 1597-1598.

Bourne, N. \& Dancer, B. N. (1986). Regeneration of protoplasts of Bacillus subtilis 168 and closely related strains. J Gen Microbiol 132, 251-255.

Ceriotti, G. (1955). Determination of nucleic acids in animal tissues. $J$ Biol Chem 214, 59-70. 
Chang, S. \& Cohen, S. N. (1979). High frequency transformation of Bacillus subtilis protoplasts by plasmid DNA. Mol \& Gen Genet 168. 111-115.

Hauser, P. M. \& Karamata, D. (1992). Ploidy of Bacillus subtili.s exfusants: the haploid nature of cells forming colonies with biparental or prototrophic phenotypes. J Gen Microbiol 138, 1077-1088

Horikoshi, K. (1991). Industrial applications. In Microorganisms in Alkaline Environments, pp. 187-246, Edited by K. Horikoshi. Weinheim: VCH Verlagsgesellschaft.
Krulwich, T. A. (1982). The fine structure of obligatory alkalophilic bacilli. FEMS Microbiol Lett 13, 299-301.

Schaeffer, P., Cami, B. \& Hotchkiss, R. D. (1976). Fusion of bacterial protoplasts. Proc Natl Acad Sci US A 73, 2151-2155.

Wyrick, P. B. \& Rogers, H. J. (1973). Isolation and characterization of cell wall-defective variants of Bacillus subtilis and Bacillus licbeniformis. J Bacteriol 116, 456-465.

Received 14 April 1994; revised 13 June 1994; accepted 4 July 1994. 